\title{
Karyological characterization of four Neotropical fish species of the genus Hisonotus (Teleostei, Loricariidae, Hypoptopomatinae) from distinct Brazilian river basins
}

\author{
Artur Antonio Andreata ${ }^{1}$, Claudio Oliveira ${ }^{2}$ and Fausto Foresti ${ }^{2}$ \\ ${ }^{1}$ Fundação Educacional de Penápolis, Penápolis, SP, Brazil. \\ ${ }^{2}$ Universidade Estadual Paulista 'Júlio de Mesquita Filho', Instituto de Biociências, Departamento de \\ Morfologia, Botucatu, SP, Brazil.
}

\begin{abstract}
The karyotypes of four Hisonotus species (two provisionally-named species A and D, $H$. nigricauda, and $H$. leucofrenatus) were found to have the same diploid number of $2 n=54$ and interstitial silver-staining nucleolus organizer regions (Ag-NORs) located on the long arm of the largest metacentric pair. The C-banding pattern appeared to be species-specific, with one group $(H$. nigricauda and the unnamed species $A$ and $D)$ being characterized by small amounts of positive $C$-banded segments and containing a sub-group (species $A$ and $D$ ) identified by a large positive C-banded segment on a small metacentric chromosome pair. The second group contained different samples of $H$. leucofrenatus, characterized by a larger amount of C-band positive segments spread over several chromosome arms. Heterochromatin appears to play an important evolutionary role in chromosome differentiation in Hisonotus species, especially in $\mathrm{H}$. leucofrenatus. The geographic isolation of several $\mathrm{H}$. leucofrenatus populations seems to have favored chromosome evolution of each sample analyzed.
\end{abstract}

Key words: fish cytogenetics, karyotypes, Ag-NORs, C-band, chromosome evolution.

Received: April 13, 2005; Accepted: September 11, 2005.

\section{Introduction}

The subfamily Hypoptopomatinae is a monophyletic group of loricariids composed of 79 species distributed in 15 genera (Schaefer, 2003). Recent taxonomic studies have revealed the existence of new genera and species (Reis and Schaefer, 1998; Isbrücker et al., 2001) and provided information for better taxa delimitation. The two Hypoptopomatinae genera Microlepidogaster and Hisonotus have, until recently, been considered as synonymous, although they are now recognized as separate and valid taxa (Schaefer, 1998). The genus Microlepidogaster is monotypic containing only M. perforatus, while all of the remaining species previously referred to as Microlepidogaster (Andreata et al., 1993; Andreata et al., 1994) have now been allocated to the genus Hisonotus (Schaefer, 1998).

Differences either in the amount or distribution of chromosomal heterochromatin as identified by the C-ban-

Send correspondence to Claudio Oliveira. Universidade Estadual Paulista 'Júlio de Mesquita Filho', Instituto de Biociências, Departamento de Morfologia, 18618-000 Botucatu, SP, Brazil. E-mail: claudio@ibb.unesp.br. ding technique has been reported to be an important evolutionary component in some fish groups, with some differences in the distribution of positive C-band segments having lead to the cytogenetic characterization of genera, species and even populations (Mantovani et al., 2000). In some species of Neotropical fish, changes in the amount or distribution of positive $\mathrm{C}$-band segments have also been associated with sex chromosome differentiation (AlmeidaToledo et al., 2001) and B chromosomes (Jesus et al., 2003).

Cytogenetic information about Hisonotus is restricted to four species for which the heterochromatin apparently played a fundamental role in karyotypic diversification, at least at a local level (Andreata et al., 1993; Andreata et al., 1994). In this paper we present the karyotypes of four Hisonotus species from distinct Brazilian river basins and compare our results with the available data for this genus.

\section{Materials and Methods}

Cytogenetic studies were carried out on four Hisonotus species from southeastern and southern 
Brazil, voucher specimens of which were deposited in the collection of the Laboratório de Biologia e Genética de Peixes (LBP), Departamento de Morfologia, Universidade Estadual Paulista (UNESP), Botucatu, São Paulo, Brazil. The specimens studied were: eight females H. nigricauda (LBP 579) from the Guaíba river near the town of Eldorado do Sul in Rio Grande do Sul state; four females $H$. leucofrenatus (LBP 735) from the Cavalo stream near the town of Jaraguá do Sul in Santa Catarina state; one female and three males Hisonotus sp., provisionally named as species A, (LBP 869) from the Paraitinga river near the town of Salesópolis in São Paulo state; and one female and two males Hisonotus sp., provisionally named as species D, (LBP 791) from Grande stream near the town of Pindamonhangaba in São Paulo state. The Hisonotus species provisionally named A and $\mathrm{D}$ are new species which will be described elsewhere $(\mathrm{H}$. A. Britski, Museu de Zoologia, Universidade de São Paulo, personal communication). The collection sites are shown in Figure 1.

Mitotic chromosome preparations were obtained from kidney and gill tissues using the air-drying technique (Foresti et al., 1993). Chromosome morphology was determined on the basis of arm ratio (Levan et al., 1964) and chromosomes were classified as metacentric, submetacentric, subtelocentric or acrocentric. Nucleolar organizer regions (Ag-NORs) were silver-stained following Howell and Black (1980) and C-banding was performed according to Sumner (1972).

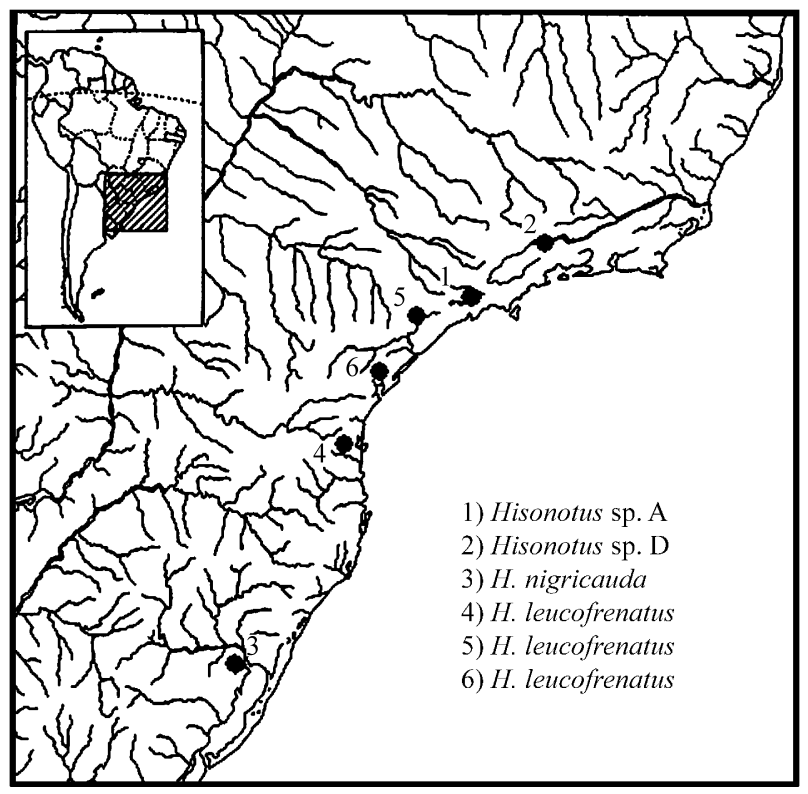

Figure 1 - Map showing the sites where the Hisonotus samples were collected. 1) Paraitinga river, Salesópolis, São Paulo State; 2) Grande stream, Pindamonhangaba, São Paulo State; 3) Guaíba river, Eldorado do Sul, Rio Grande do Sul State; 4) Cavalo stream, Jaraguá do Sul, Santa Catarina State; 5) Poço Grande stream, Juquiá, São Paulo State; 6) Marumbi river, Morretes, Paraná State. The numbers 5 and 6 correspond to the collecting sites of $H$. leucofrenatus studied by Andreata et al. (1993).

\section{Results}

We found that Hisonotus species A and D shared a similar karyotypic structure composed of 13 metacentric pairs, 13 submetacentric pairs and 1 subtelocentric pair (Figure 2), the only conspicuous difference between these two species being that in species A the first and second metacentric pairs were of almost the same size while in species $\mathrm{D}$ the first metacentric pair was larger than the second metacentric pair (Figure 2).

Regarding the other two species, $H$. nigricauda had 13 metacentric pairs, 10 submetacentric pairs and 4 subtelocentric pairs (Figure 3A), whilst H. leucofrenatus had 11 metacentric pairs, 12 submetacentric pairs, 3 subtelo-
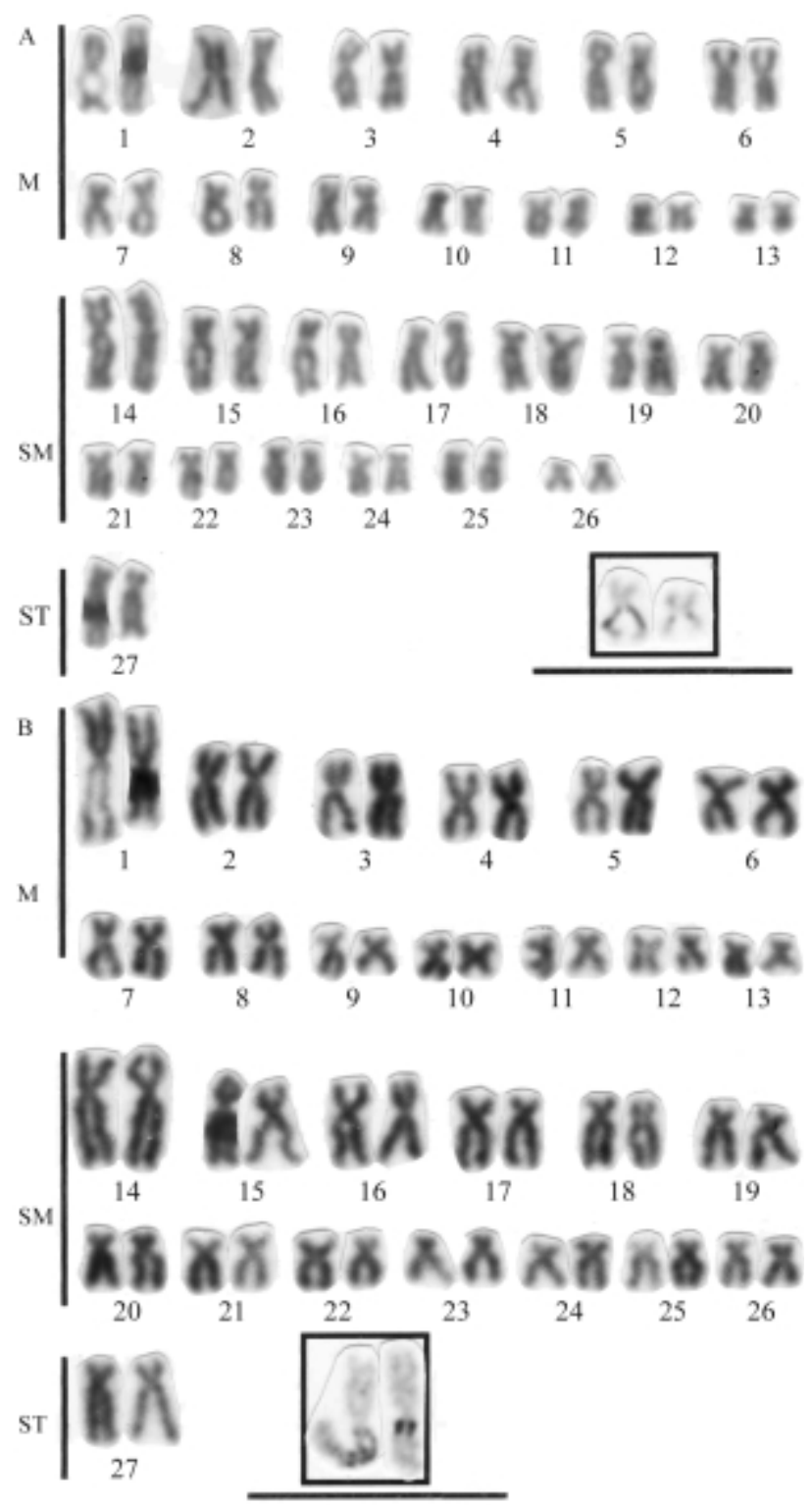

Figure 2 - Giemsa stained karyotypes of Hisonotus species A and D from São Paulo State. A = species A from Salesópolis; B = species D from Pindamonhangaba. Inset, the Ag-NOR-bearing chromosome pairs. Bars $=10 \mu \mathrm{m}$. 
centric pairs and 1 pair of acrocentric chromosomes (Figure 3B).

All four species showed interstitial Ag-NORs located on the long arms of the largest metacentric pair (Figures 2 and 3). Positive C-banded segments were restricted to the pericentromeric and terminal regions of several chromo-
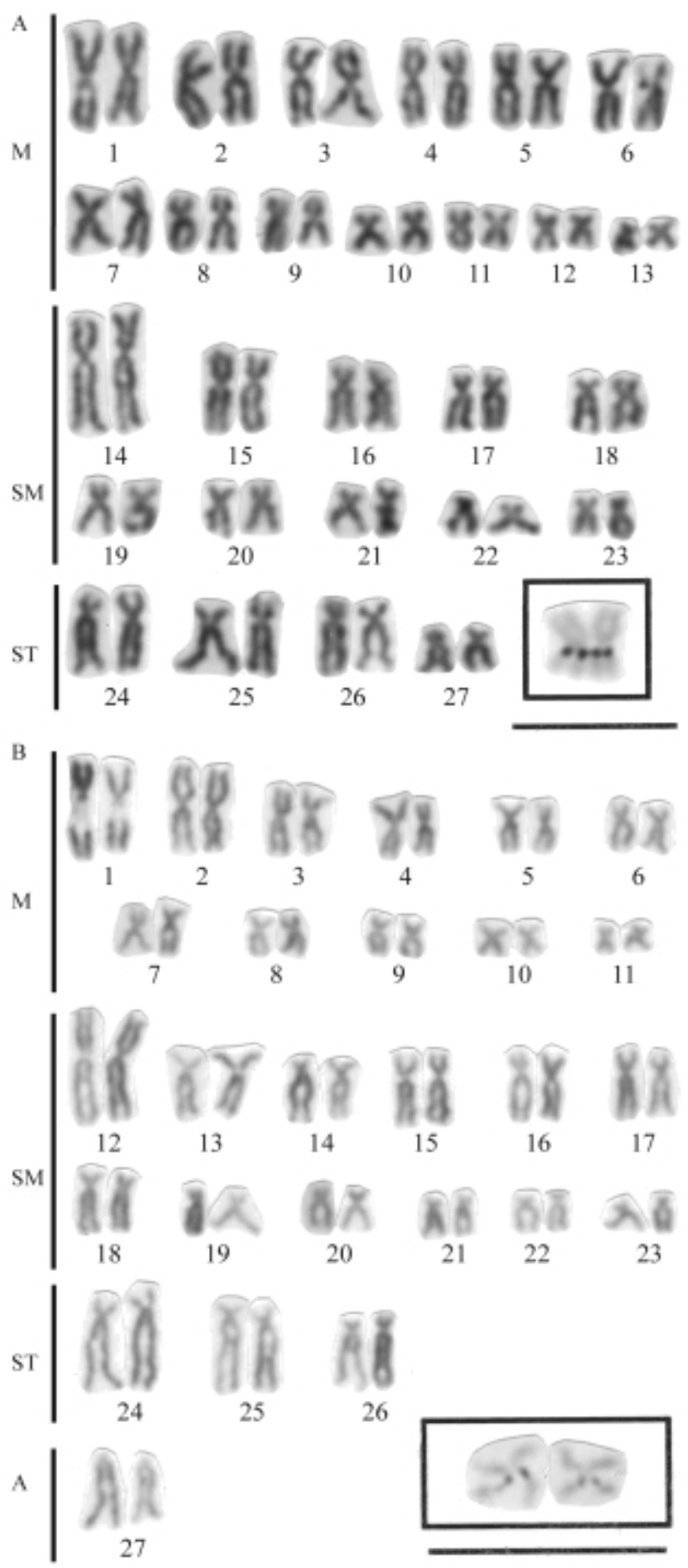

Figure 3 - Giemsa stained karyotypes of Hisonotus species. $\mathrm{A}=H$. nigricauda from Eldorado do Sul (Rio Grande do Sul State); $\mathrm{B}=H$. leucofrenatus from Jaraguá do Sul (Santa Catarina State). Inset, the AgNORs-carrier pairs. Bars $=10 \mu \mathrm{m}$. somes of Hisonotus species A (Figure 4A), H. nigricauda (Figure 4B) and Hisonotus species D (Figure 4C). We also found that Hisonotus species A and D presented a small pair of metacentric chromosomes with a large positive C-banded block on the long arm (Figures 4A and 4C). Comparing the same chromosome segments, the Ag-NOR segments were negatively C-banded in Hisonotus species A and positively C-banded in species D (Figure 4). In the case of $H$. leucofrenatus we found several positive C-band segments located on the long arm of several chromosomes, including the largest Ag-NOR-bearing chromosomes (Figure 4D).

\section{Discussion}

Our cytogenetic analyses revealed that the four Hisonotus species studied shared the same diploid number $(2 n=54)$ and were also characterized by the presence of interstitial Ag-NORs located on the long arm of the largest metacentric pair. The same diploid number and interstitial Ag-NORs have being found in almost all species of Hypoptopomatinae (Andreata et al., 1992; Andreata et al., 1993; Andreata et al., 1994), reinforcing the hypothesis that

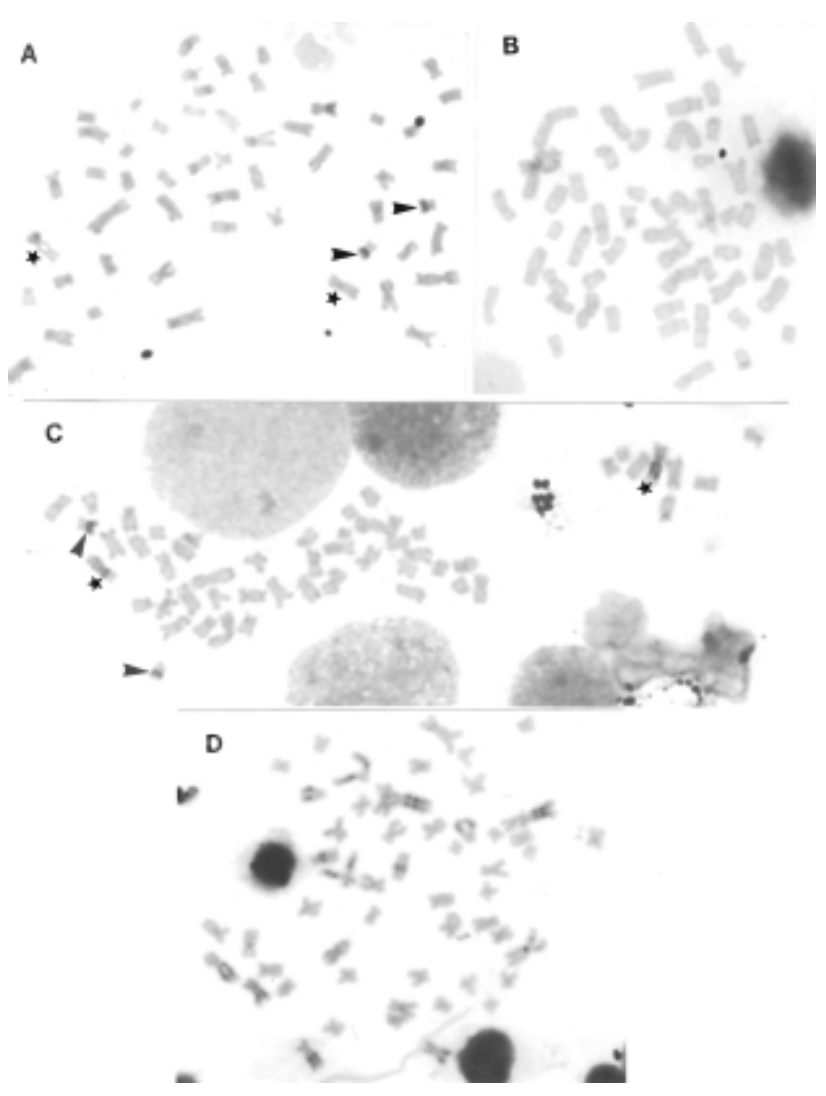

Figure 4 - C-banded mitotic metaphase of Hisonotus species. $\mathrm{A}=$ Hisonotus species A from Salesópolis (São Paulo State); $\mathrm{B}=H$. nigricauda from Eldorado do Sul (Rio Grande do Sul State); $\mathrm{C}=$ Hisonotus species D from Pindamonhangaba (São Paulo State); and $\mathrm{D}=$ H. leucofrenatus from Jaraguá do Sul (Santa Catarina State). Arrows point to marker chromosomes shared by two species. Stars indicate Ag-NOR-bearing chromosomes. 
this group is karyotypically very conserved (Andreata et al., 1994).

Although the species of the subfamily Hypoptopomatinae show a similar karyotypic macrostructure, the Cbanding pattern has been useful in distinguishing species limits and determining local samples of some species (Andreata et al., 1993).

Our four Hisonotus species formed two groups based on the number and distribution of positive C-banded segments. Group 1 contained species A, D and H. nigricauda and was characterized by chromosomes which had a small number of positive C-banded segments restricted to the pericentromeric and terminal regions of the chromosomes. This group contained a subgroup consisting of species A and D, both of which shared the same cytotype (Figure 2) and exhibited a small metacentric chromosome pair with a large positive $\mathrm{C}$-banded block in the long arms (Figures 4A and 4C). Group 2 contained the $H$. leucofrenatus specimens captured by us at Jaraguá (Figure 4D) and data from specimens of the same species captured in the Brazilian states of São Paulo and Paraná by Andreata et al. (1993), members of this group being characterized by a large number of positive C-band segments spread over several chromosome arms.

We found that Hisonotus species A and D shared similar cytotypes, Ag-NOR distribution and C-banding patterns but differed in the size of the first metacentric pair and by the fact that the $\mathrm{C}$-banding was negative in species $\mathrm{A}$ and positive in species $\mathrm{D}$. These two differences may be related in that the accumulation of positive $\mathrm{C}$-band chromatin could promote an increase in the size of the first metacentric pair. These two species may have descended from a common ancestor but are now completely isolated because species A occurs in streams of the Tietê river basin and species D in streams of southeastern Brazilian coastal river basins (Figure 1). Geological studies have shown that although these two hydrological systems are now separated they were connected until the Miocene (Lundberg, 1998; Malabarba, 1998). The karyotypic differences observed between species A and D could have been fixed after their separation. Cytogenetic studies involving other groups of fish inhabiting the same region seem to support the idea that chromosome rearrangements become fixed after species separation (Oliveira et al., 1993; Guimarães et al., 1995).

The role of heterochromatin in the evolution of chromosome has long been the subject of intensive discussion. The different views on the role of heterochromatin during development and evolution have been reviewed by John (1988) who states that mechanisms such as multiple replications, unequal exchanges, amplifications, accumulations and deletions can lead to the quantitative variation of heterochromatin within and between species. Such variation could favor the formation of distinct groups of organisms and contributes to speciation, Redi et al. (2001) having suggested that speciation related to quantitative pro- cess of heterochromatin differentiation may have occurred in organisms as diverse as rodents and Drosophila.

In fish, several studies have shown that heterochromatin (identified by the C-band technique) is an important element in chromosome differentiation (Caputo et al., 1997; Artoni and Bertollo, 1999; Margarido and Galetti Jr, 2000). The fish Astyanax scabripinnis has been intensively investigated cytogenetically and has shown broad chromosome diversity, frequently related to the amount and distribution of positive C-band segments (Mantovani et al., 2000). Chromosomal differentiation in A. scabripinnis has often been related to its population structure, made up of small and isolated populations living in the headwaters of small rivers. A similar situation seems to occur with $H$. leucofrenatus in that it too exists in small isolated populations, so accumulation of heterochromatin should have occurred in the samples analyzed in our study, and other studies. Although Andreata et al. (1993) identified a putative sex chromosome system in two f $H$. leucofrenatus samples this was not found in the present study, suggesting that changes in positive C-banded segments had occurred and have been independently fixed in the samples.

Besides the conspicuous differences in heterochromatin distribution, the karyotype of $H$. leucofrenatus also differs from that of the other species analyzed by its different chromosome formulae. This difference may be related to the presence of several positive C-band segments since the accumulation of such segments could change chromosome morphology. However, it is not possible to discard the hypothesis that several pericentric inversions have been fixed in this species, changing its karyotypic formulae.

The karyotypic differences observed between the $H$. leucofrenatus sample studied here and those studied by Andreata et al. (1993) might be related to the formation of the southeastern Brazilian coastal rivers because the main rivers in this area are now separated by geographic barriers that can suppress the dispersion of individual fish. Previous studies have revealed differences between samples of several fish groups inhabiting this area, and some studies have suggested that vicariant events were the most important force acting in the speciation processes of these groups (Weitzman et al., 1988; Reis and Schaefer, 1998). Cytogenetic studies have also revealed the occurrence of chromosome diversification in other fish species occurring in this area (Oliveira et al., 1993; Guimarães et al., 1995). It thus appears that the chromosome differentiation observed in the H. leucofrenatus samples may have resulted from allopatric speciation associated with the separation of the coastal rivers in southeastern Brazil.

\section{Acknowledgments}

The authors are grateful to H.A. Britski for the identification of the species and R. Devidé for technical assistance. We also thank G.T. Rocha, O. Moreira-Filho and M.F.Z.D. Silva for their critical review of the original 
manuscript. Grants from FAPESP, CNPq, and FUNEPE (Fundação Educacional de Penápolis) are gratefully acknowledged.

\section{References}

Almeida-Toledo LF, Foresti F, Péquignot EV and Daniel-Silva MFZ (2001) XX:XY sex chromosome system with X heterochromatinization: An early stage of sex chromosome differentiation in the Neotropic electric eel Eigenmannia virescens. Cytogenet Cell Genet 95:73-78.

Andreata AA, Almeida-Toledo LF, Oliveira C and Toledo-Filho SA (1992) Chromosome studies in Hypoptopomatinae (Pisces, Siluriformes, Loricariidae): I. XX/XY sex chromosome heteromorphism in Pseudotocinclus tietensis. Cytologia 57:369-372.

Andreata AA, Almeida-Toledo LF, Oliveira C and Toledo-Filho SA (1993) Chromosome studies in Hypoptopomatinae (Pisces, Siluriformes, Loricariidae). II. ZZ/ZW Sex-chromosome system, B chromosomes, and constitutive heterochromatin differentiation in Microlepidogaster leucofrenatus. Cytogenet Cell Genet 63:215-220.

Andreata AA, Almeida-Toledo LF, Oliveira C and Toledo-Filho SA (1994) Cytogenetic studies on the subfamily Hypoptopomatinae (Pisces, Siluriformes, Loricariidae). III. Analysis of seven species. Caryologia 47:27-37.

Artoni RF and Bertollo LAC (1999) Nature and distribution of constitutive heterochromatin in fishes, genus Hypostomus (Loricariidae). Genetica 106:209-214.

Caputo V, Marchegiani F, Sorice M and Olmo E (1997) Heterochromatin heterogeneity and chromosome variability in four species of gobiid fishes (Perciformes, Gobiidae). Cytogenet Cell Genet 79:266-271.

Foresti F, Oliveira C and Almeida-Toledo LF (1993) A method for chromosome preparations from large specimens of fishes using in vitro short treatment with colchicine. Experientia 49:810-813

Guimarães IN, Almeida-Toledo LF, Oliveira C, Foresti F and Toledo-Filho SA (1995) Cytogenetic studies in three species of Glandulocaudinae (Pisces, Characiformes, Characidae). Rev Brasil Genet 18:185-189.

Howell WM and Black DA (1980) Controlled silver staining of nucleolus organizer regions with a protective colloidal developer: A 1-step method. Experientia 36:1014-1015.

Isbrücker IJH, Seidel i, Michels jp, Schraml E and Werner a (2001) diagnose vierzehn neuer gattungen der familie Loricariidae Rafinesque, 1815 (Teleostei, Ostariophysi). DATZ - Sonderheft Harnischwelse 2:17-24.

Jesus CM, Galetti Jr. PM, Valentini SR and Moreira-Filho O (2003) Molecular characterization and chromosomal localization of two families of satellite DNA in Prochilodus lineatus (Pisces, Prochilodontidae), a species with B chromosomes. Genetica 118:25-32.
John B (1988) The biology of heterochromatin. In: Verma RS (ed) Heterochromatin. Cambridge University Press, Cambridge, pp 1-147.

Levan A, Fredga K and Sandberg AA (1964) Nomenclature for centromeric position on chromosomes. Hereditas 52:201220.

Lundberg JG (1998) The temporal context for the diversification of neotropical fishes. In: Malabarba LR, Reis RE, Vari RP, Lucena ZMS and Lucena Cas (eds) Phylogeny and Classification of Neotropical Fishes. Edipucrs, Porto Alegre, pp 49-68.

Malabarba MCSL (1998) Phylogeny of fossil Characiformes and paleobiogeography of the Tremembé formation, São Paulo, Brasil. In: Malabarba LR, Reis RE, Vari RP, Lucena ZMS and Lucena CAS (eds) Phylogeny and Classification of Neotropical Fishes. Edipucrs, Porto Alegre, pp 69-84.

Mantovani M, Abel LDS, Mestriner CA and Moreira-Filho O (2000) Accentuated polymorphism of heterochromatin and nucleolar organizer regions in Astyanax scabripinnis (Pisces, Characidae): Tools for understanding karyotypic evolution. Genetica 109:161-168.

Margarido VP and Galetti Jr. PM (2000) Amplification of a GC-rich heterochromatin in the freshwater fish Leporinus desmotes (Characiformes, Anostomidae). Genet Mol Biol 23:569-573.

Oliveira C, Almeida-Toledo LF, Mori L and Toledo-Filho SA (1993) Cytogenetic and DNA content studies on armoured catfishes of the genus Corydoras (Pisces, Siluriformes, Callichthyidae) from the southeast coast of Brazil. Rev Bras Genet 16:617-629.

Redi CA, Garagna S, Zacharias H, Zuccotti M and Capanna E (2001) The other chromatin. Chromosoma 110:136-147.

Reis RE and Schaefer SA (1998) New cascudinhos from Southern Brazil: Systematics, endemism, and relationships (Siluriformes, Loricariidae, Hypoptopomatinae). Am Mus Novit 3254:1-25.

Schaefer SA (1998) Conflict and resolution: Impact of new taxa on phylogenetic studies of the neotropical cascudinhos (Siluroidei, Loricariidae). In: Malabarba LR, Reis RE, Vari RP, Lucena ZMS and Lucena CAS (eds) Phylogeny and Classification of Neotropical Fishes. Edipucrs, Porto Alegre, pp 375-400.

Schaefer SA (2003) Hypoptopomatinae. In: Reis RE, Kullander SO and Ferraris Jr. CJ (eds) Check List of the Freshwater Fishes of South America. Edipucrs, Porto Alegre, pp 321329.

Sumner AT (1972) A simple technique for demonstrating centromeric heterochromatin. Exp Cell Res 75:304-306.

Weitzman SH, Menezes NA and Weitzman MJ (1988) Phylogenetic biogeography of the Glandulocaudini (Teleostei: Characiformes, Characidae) with comments on the distributions of others freshwater fishes in eastern and southeastern Brazil. Proceedings of the Workshop on Neotropical Distribution Patterns. Academia Brasileira de Ciências, Rio de Janeiro, pp 379-427.

Associate Editor: Yatiyo Yonenaga Yassuda 